\title{
ЗЕМЛЯНКИ И ПОЛУЗЕМЛЯНКИ САМОСДЕЛЬСКОГО ГОРОДИЩА (ПО МАТЕРИАЛАМ І РАСКОПА)
}

\author{
(2021 г. Э.Д. Зиливинская
}

Статья посвящена публикации полуземлянок и землянки, исследованных на Самосдельском городище IX-XIV вв., расположенном в низовьях Волги. Две полуземлянки, относящиеся к раннему и среднему периодам существования городища, представляли собой неглубокие ямы прямоугольной формы. Стены их были каркасными: у одной из жердей, обмазанных глиной, у другой - пространство между жердями заложено сырцовым кирпичом. Аналогии этим постройкам находятся в донской части Хазарского каганата и в Волжской Болгарии. Постройка XII в. интересна и тем, что в ней найден большой клад свинцовых слитков. Большая землянка позднего периода имела глубину более 2 м. Стены ее были обложены обломками обожженных кирпичей. Обилие перестроек свидетельствует о том, что землянка существовала длительное время. Состав находок говорит о том, что обитатели ее были людьми зажиточными, и в землянке могла находиться ремесленная мастерская. Полных аналогий эта постройка не имеет.

Ключевые слова: археология, средневековье, Нижнее Поволжье, Хазарский каганат, Саксин, Золотая Орда, городище, полуземлянки, землянки, жилища, хозяйственные постройки/

\section{DUGOUTS AND SEMI-DUGOUTS OF SAMOSDELKA SETTLEMENT (BASED ON MATERIALS FROM EXCAVATION I)}

\section{E. D. Zilivinskaya}

The paper is aimed at the publication of semi-dugouts and a dugout investigated at Samosdelka settlement of the $9^{\text {th }}-14^{\text {th }}$ centuries located in the Lower Volga. Two semi-dugouts dating back to the early and middle periods of the settlement's existence were shallow rectangular pits. Their walls had a frame structure: one of the walls was composed of poles plastered with clay, and another one had the space between the poles laid with unfired brick. Analogies to these buildings are located in the Don part of Khazar Kaganate and in Volga Bolgaria. The structure of the $12^{\text {th }}$ century it is also interesting because a large hoard of lead ingots was found inside. A large dugout of the late period had a depth of more than 2 meters. Its walls were lined with fragments of fired bricks. The large number of reconstructions indicates that the dugout existed for a long period of time. The composition of the finds suggests that its inhabitants were wealthy people, and a craft workshop could have been located in the dugout. The building has no complete analogies.

Keywords: archaeology, Middle Ages, Lower Volga region, Khazar Kaganate, Saksin, Golden Horde, settlement, semi-dugouts, dugouts, dwellings, household structures.

Самосдельское городище - довольно известный памятник, раскопки на котором ведутся уже более 20 лет. Он находится в Астраханской области и расположен в самом центре дельты Волги. Площадь поселения в период его расцвета достигала 4 кв. км. Нижние слои его датируются IX-X вв., средние - XI - первой половиной XIII вв., доживает поселение до первой половины XIV в., после чего территория попадает под затопление в результате трансгрессии Каспийского моря. Ряд данных (планиграфия, наличие построек из обожженного кирпича, возможно, крепости, юртообразных жилищ в нижних слоях, керамики хазарского времени, а также радиоуглеродные даты) позволил исследователям предположить, что в $\mathrm{IX}-\mathrm{X}$ вв. здесь могла располагаться столи- ца Хазарского каганата Итиль (Зиливинская, Васильев, 2008). В постхазарское время на месте хазарского города возникает город Саксин, известный до настоящего времени лишь по письменным источникам (Васильев, 2012). В золотоордынский период город приходит в упадок и представляет собой небольшое, постепенно затапливаемое поселение.

Культурные напластования Самосдельского городища достигают мощности 3 м, и во всех слоях прослеживаются остатки различных сооружений, как жилых, так и хозяйственного назначения. В нижних слоях найдены слегка заглубленные в землю юртообразные постройки, которые исследователи связывают с оседанием на землю кочевого населения (Флеров, 1996, с. 59-60). Впрочем, на Само- 
сдельском городище юртообразные жилища встречаются и в более поздний период, в XI-XII вв. (Болдырева, Васильев, Зиливинская, 2020). Уже в нижних слоях появляются наземные сооружения со стенами из жердей, обмазанных глиной (так называемые турлучные постройки). Дома, построенные в этой технике, продолжают существовать в течение всей жизни городища. B XI-XII вв. активно строятся дома из обожженного кирпича вторичного использования. Стены в них возводились из целых и битых кирпичей полностью или имели кирпичные цоколи. Дома часто были многокомнатными. В XIII-XIV вв. в строительстве также применялся обожженный кирпич вторичного использования. Так как это был все тот же материал, происходящий из нижних слоев, то целые кирпичи встречаются редко, а куски битого становятся мельче. Дома этого периода в основном небольшие, однокомнатные. Стены в них строятся в различной технике: встречаются целиком кирпичные и сырцовые, сырцовые и турлучные на кирпичном цоколе, просто турлучные. Большинство построек наземные, но некоторые имеют слегка (20-30 см) заглубленный относительно дневной поверхности пол. Небольшая часть сооружений была заглублена в землю достаточно сильно.

В изучении таких сооружений, как полуземлянки, существуют определенные проблемы. Подробно этот вопрос был рассмотрен М.Д. Полубояриновой (Полубояринова, 2016 , c. 9-13). С одной стороны, существование такой формы жилищ, как полуземлянки, отрицать невозможно, так как они появляются у различных народов с древности и существуют практически до настоящего времени. Однако при раскопках их можно спутать с подпольями наземных домов. В частности, об этом ведутся ожесточенные споры среди исследователей древнерусских жилищ. Главным критерием, позволяющим отличить полуземлянку от подполья, является наличие очага на ее дне. Многие исследователи совершенно справедливо отмечают, что печь никак не может находиться под деревянным полом наземного жилища, следовательно, если она находится на дне котлована постройки, то последняя является полуземлянкой. Хочу, однако, заметить, что такой принцип может быть применен только к жилым полуземлянкам. В хозяйственных и производственных помещениях печей может не быть. Кроме того, в регионах с теплым климатом сооружения могут отапли- ваться не стационарными очагами, а переносными жаровнями.

Также нет четкого определения, с какой глубины залегания пола жилище можно считать не наземным, а полуземляночным. В научной литературе параллельно с термином «полуземлянка» применяются также словосочетания «постройка с углубленным основанием», «сооружение с неглубоким земляным котлованом», «материковые углубления» (Полубояринова, 2016, с. 10-11). Нет четкого разграничения и между терминами «полуземлянка» и «землянка». М.Д. Полубояринова предлагает считать полуземлянками сооружения с котлованом глубиной 0,5-1,8 м, на дне которого находится печь или очаг (Полубояринова, 2016, с. 11). Данное определение представляется совершенно обоснованным, следует лишь учитывать, что в нежилых полуземлянках очага может не быть. Сооружения с полом, заглубленным больше чем на 1,8 м (то есть на глубину выше человеческого роста), на мой взгляд, можно называть землянками.

На Самосдельском городище полуземлянки и землянки встречены при раскопках слоев различных хронологических периодов.

При исследовании ранних слоев на I раскопе было расчищено сооружение 39, заглубленное в землю и имевшее турлучные стены (рис. 1). Пятно ямы сооружения было зафиксировано на уровне XI штыка. Контур его хорошо прослеживался с северной и западной сторон, а также в северной части восточной стенки и в западной части южной, так как в этих частях стенки котлована были материковыми. Здесь в материке было прослежено большое количество жердевых ямок от каркаса стен сооружения. Ямки имели диаметр от 2 до 8 см и различную глубину (2-6 см). Они располагались без особого порядка вдоль стен котлована жилища, образуя полосы шириной 50-80 см. В остальных частях контур жилища был перерезан различными ямами. Сооружение имело прямоугольную форму со скругленными углами и было ориентировано длинной осью вдоль оси запад - восток с небольшим отклонением к югу. Длина его 3,4 м, ширина 2,2 м. Пол сооружения был заглублен примерно на 75 см относительно уровня материка. Уровень материкового пола сохранился в виде небольших фрагментов в восточной части сооружения между ямами 239 и 240, а также в виде ступеньки шириной 8-30 см, которая осталась вдоль западной стенки сооружения на борту ямы 250. Северная стенка сооружения 39 в восточной части 

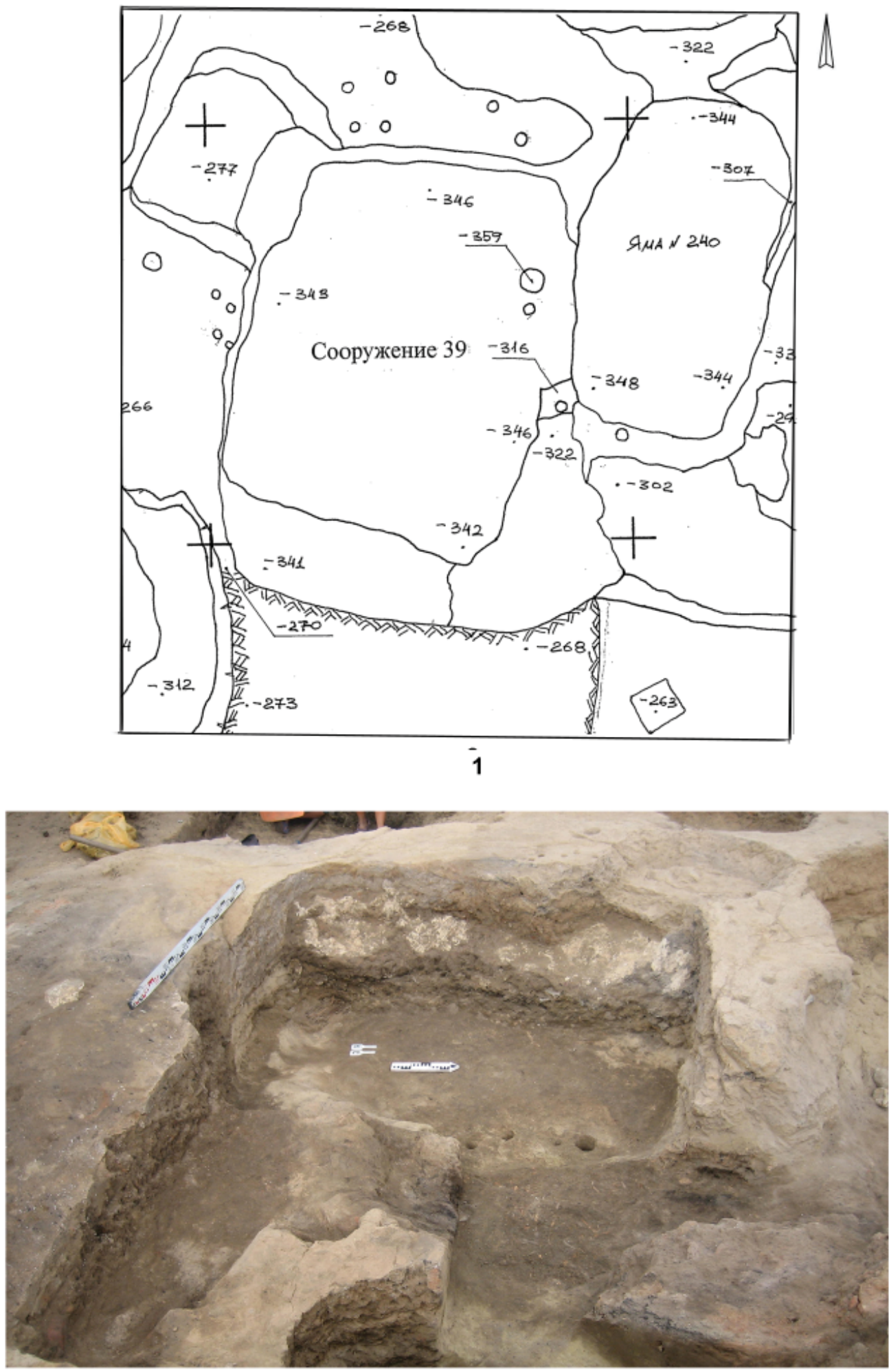

2

Рис. 1. Сооружение 39: 1 - план; 2 - вид с востока

Fig. 1. Building 39: 1 - plan; 2 - view from the east

была разрушена с северной стороны ямой 189, a с южной стороны ямой 240. ЮВ угол также несколькими ямами. В пределах сооружения находятся также разрушившая его яма 239. В свою очередь, сооружение 39 своей западной частью перерезает яму 250. В связи с такой изрезанностью ямами интерьер соору- жения (если таковой имелся) прослежен быть не мог. Находки в сооружении довольно невыразительные: донце гончарного кувшина с тамгой в виде «ветки», три лопатки мелкого рогатого скота со следами обработки, костяное изделие и железный крючок. По фрагменту красноглиняного блюда с зеленой поливой, 
декорированного в технике «сграффито», сооружение можно датировать XI в., однако этот материал может происходить из перерезавших его более поздних ям, а сама полуземлянка относиться к более раннему периоду.

На I раскопе на уровне V штыка было выявлено сооружение 23 , которое также являлось полуземлянкой. При зачистке по слою появилось пятно сырцового заплыва, в котором прослеживались отдельные сырцовые кирпичи. Оно имело прямоугольную форму, размеры $3,4 \times 3,0$ м, и было вытянуто по оси 3-В. Заполнение сооружения в верхней части состояло из расплывшейся сырцовой массы, под которой залегал плотный коричневый суглинок с обломками кирпичей. На глубине 50-90 см от поверхности обнаружения яма сооружения была заполнена плотным кирпичным завалом, который продолжался практически до дна сооружения. В заполнении сооружения № 23 были найдены многочисленные фрагменты керамики, в основном красноглиняной гончарной, кости животных и рыб, рыбья чешуя. После разборки завалов сооружение 23 было расчищено. Оно представляло собой прямоугольную в плане яму размерами 3,6×2,4-2,8 м, вытянутую в меридиональном направлении (рис. 2). Стенки ямы ровные, отвесные. Вдоль 3 стенки была сделана ступень шириной 30-35 см. Поверхность ее находилась на 25-30 см ниже края ямы. Дно ямы плоское, ровное, с некоторым уклоном к северо-западу, глубина ямы составляла около 1 м. Вдоль всех четырех стенок ямы находилась земляная суфа. Суфа была сделана довольно небрежно, стенки ее не слишком ровные, высота - 15-25 см. Западная часть суфы про краю была укреплена сильно расплывшимися сырцовыми кирпичами и обломками обожженных кирпичей, которые были положены на ее поверхность вдоль края. Ширина западной, северной и восточной частей суфы 60-100 см. Вдоль южной стенки суфа была значительно уже, всего 25-50 см. Вероятно, южная суфа представляла собой ступеньку, ведущую к выходу из сооружения, который находился с южной стороны.

На суфе в сооружении 23 были найдены различные предметы. У южной стенки ямы, в 70 см от юго-западного ее угла стояла нижняя часть большого гончарного сосуда (хумчи) диаметром 45 см. Развал еще одной хумчи находился в северо-восточном углу помещения на суфе (рис. 3: 1). Наибольшая концентрация рыбьих костей и чешуи была найдена вокруг этих сосудов. Возможно, в них хранилась рыба. На восточной суфе, вдоль борта ямы была положена доска длиной 90 см и шириной 15 см. В юго-восточном углу в суфе находилась яма неправильно овальной формы размерами $80 \times 40$ см и глубиной 20 см. Яма была наполнена свинцовыми слитками различной формы и размера (рис. 3: 3). Слитки, вероятно, хранились в мешке, так как они спеклись в единый ком и между отдельными слитками совсем не было земли. Возле этого скопления на суфе лежали 8 крупных слитков пирамидальной и призматической форм. Еще одно скопление небольших свинцовых слитков было найдено в яме № 165, расположенной у северной стены сооружения. Небольшая овальная яма $(30 \times 25$ см) была заполнена мелкими свинцовыми слитками, также, вероятно, лежавшими в мешочке. Назначение слитков неизвестно, общий вес их составлял около 285 кг. На южной суфе лежал массивный железный предмет изогнутой формы длиной его около 30 см. Предмет сильно окислен, поэтому можно только предполагать, что он представлял собой серп (рис. 3: 4). В северо-восточном углу помещения на суфе лежали два разбитых жернова диаметром 45 см (рис. 3: 2). После того как их сняли, под ними обнаружилась еще одна ямка, заполненная свинцовыми слитками. В полу сооружения 23 также были обнаружены две ямы.

В заполнении сооружения кроме фрагментов красноглиняной неполивной керамики были найдены многочисленные металлические предметы. Среди них фрагмент медного перстня с стеклянной вставкой, шесть железных цилиндрических замков и множество железных предметов двух видов: плоские предметы асимметрично ромбовидной формы с черешком общей длиной 4,5-6 см и диски диаметром около 2,5 cм также с черешком с одной стороны. Эти плоские предметы, вероятнее всего, являлись железными накладками на деревянную шкатулку или сундучок.

Судя по интерьеру и предметам, найденным внутри, сооружение 23 не было жилым, а представляло собой хозяйственную постройку, а именно полуземлянку. В нижней части ее стенами являлись земляные стенки ямы. С уровня дневной поверхности стены были каркасными. Столбовые ямы каркаса были найдены снаружи у юго-западного, юговосточного углов и у северной стенки котлована землянки. Диаметр ям в среднем около 20 см. Вдоль западного и северного бортов ямы сооружения прослеживалась полоса желтого сырцового оплывшего развала. Таким обра- 


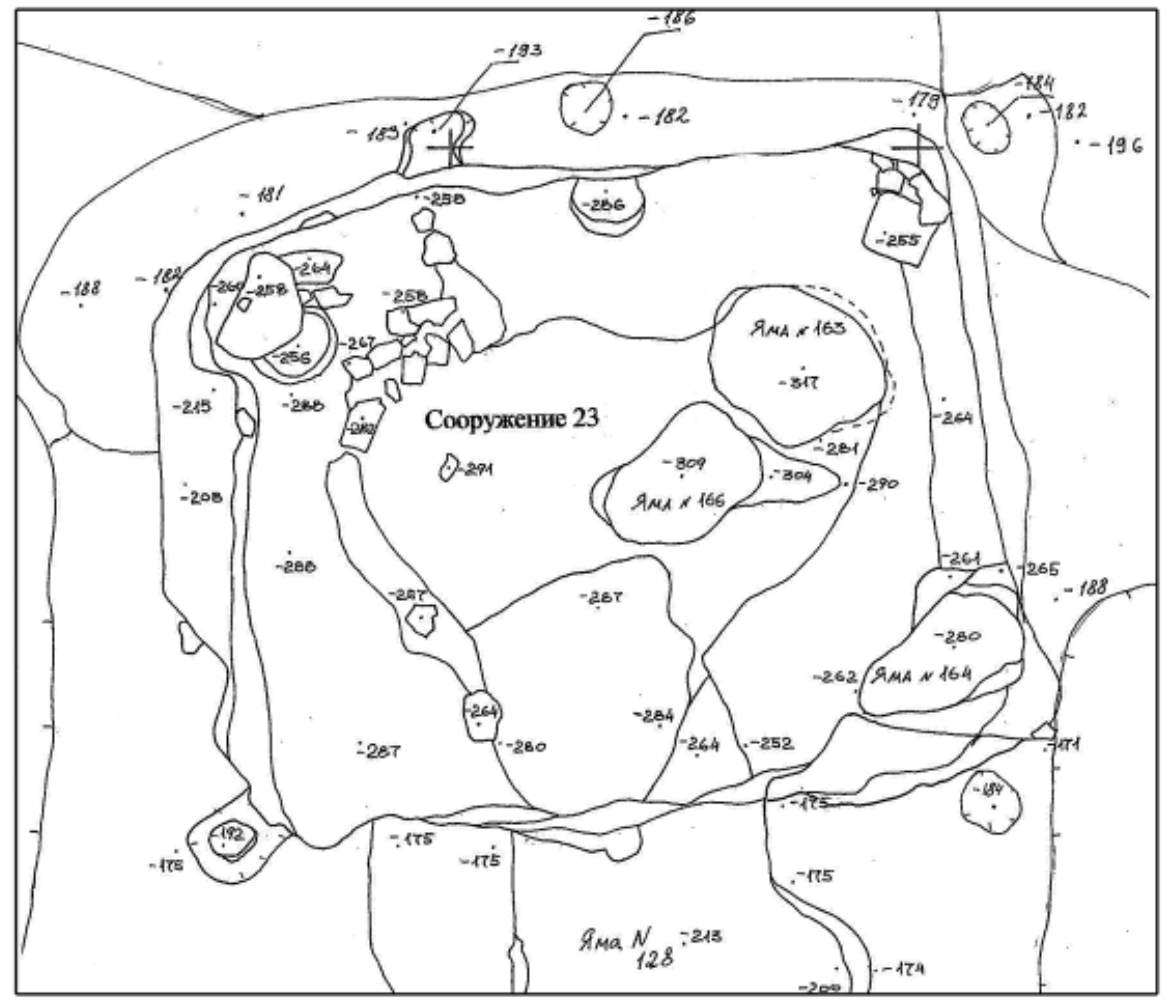



1

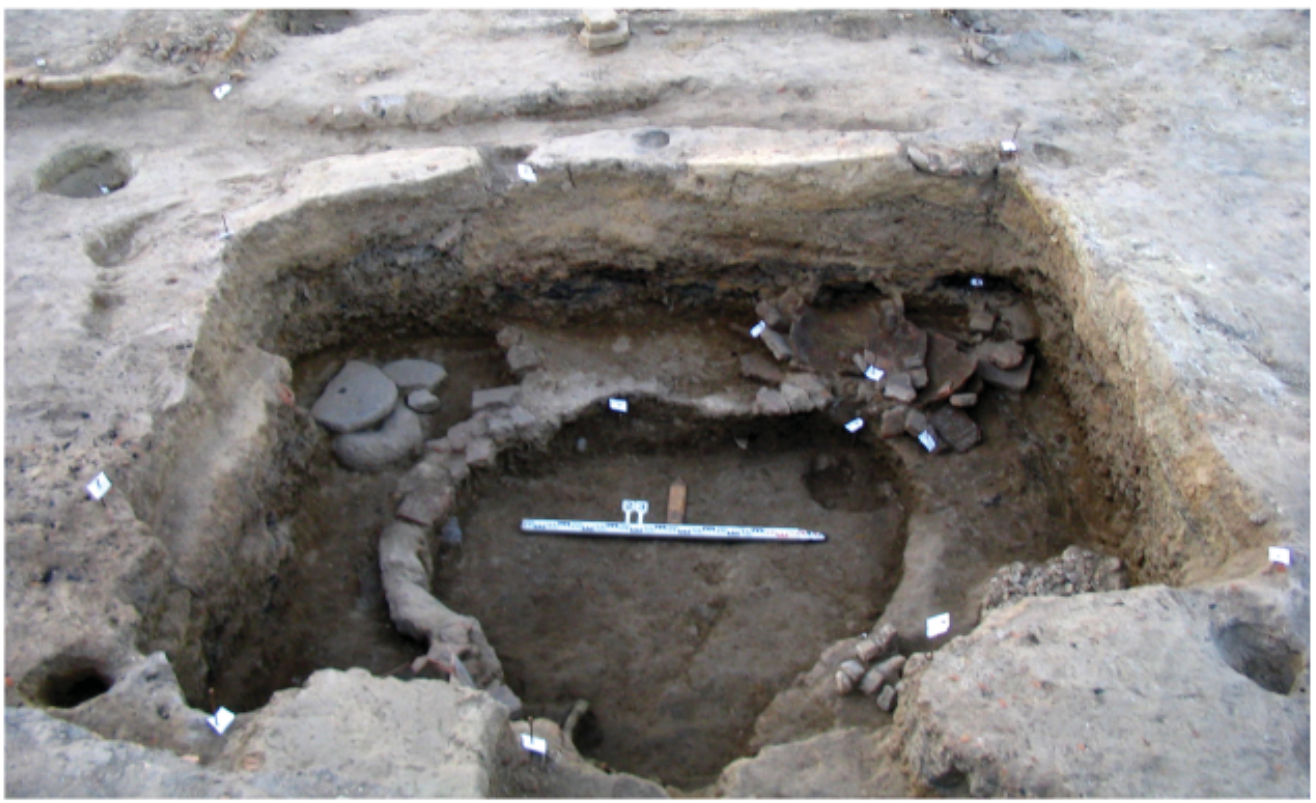

2

Рис. 2. Сооружение 23: 1 - план; 2 - вид с юга

Fig. 2. Building 23: 1 - plan; 2 - view from the south

зом, вероятно, в верхней части стенки полуземлянки были фахверковыми, сырцовыми на деревянном каркасе. Судя по обилию обломков обожженных кирпичей в заполнении ямы, они также использовались в кладке.

В верхних слоях была найдена и исследована землянка № 1. Она представляла собой прямо- угольную в плане яму, стенки которой облицованы крупными обломками кирпича на глиняном растворе (рис. 4-6). Кирпичи повернуты торцами вовнутрь помещения. Длина землянки (по оси С-Ю) составляла 5,6 м, ширина (по оси 3-B) - 4,6-4,8 м. С северной стороны в помещение вел вход в виде коридора шириной $120 \mathrm{cm.}$ 


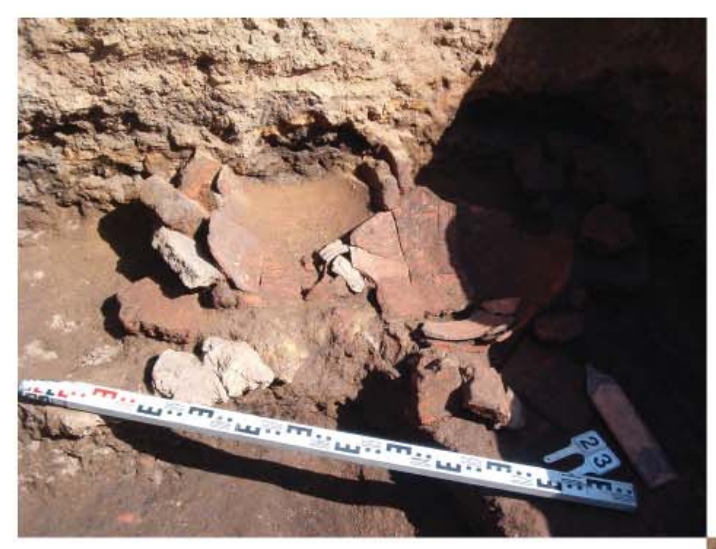

1
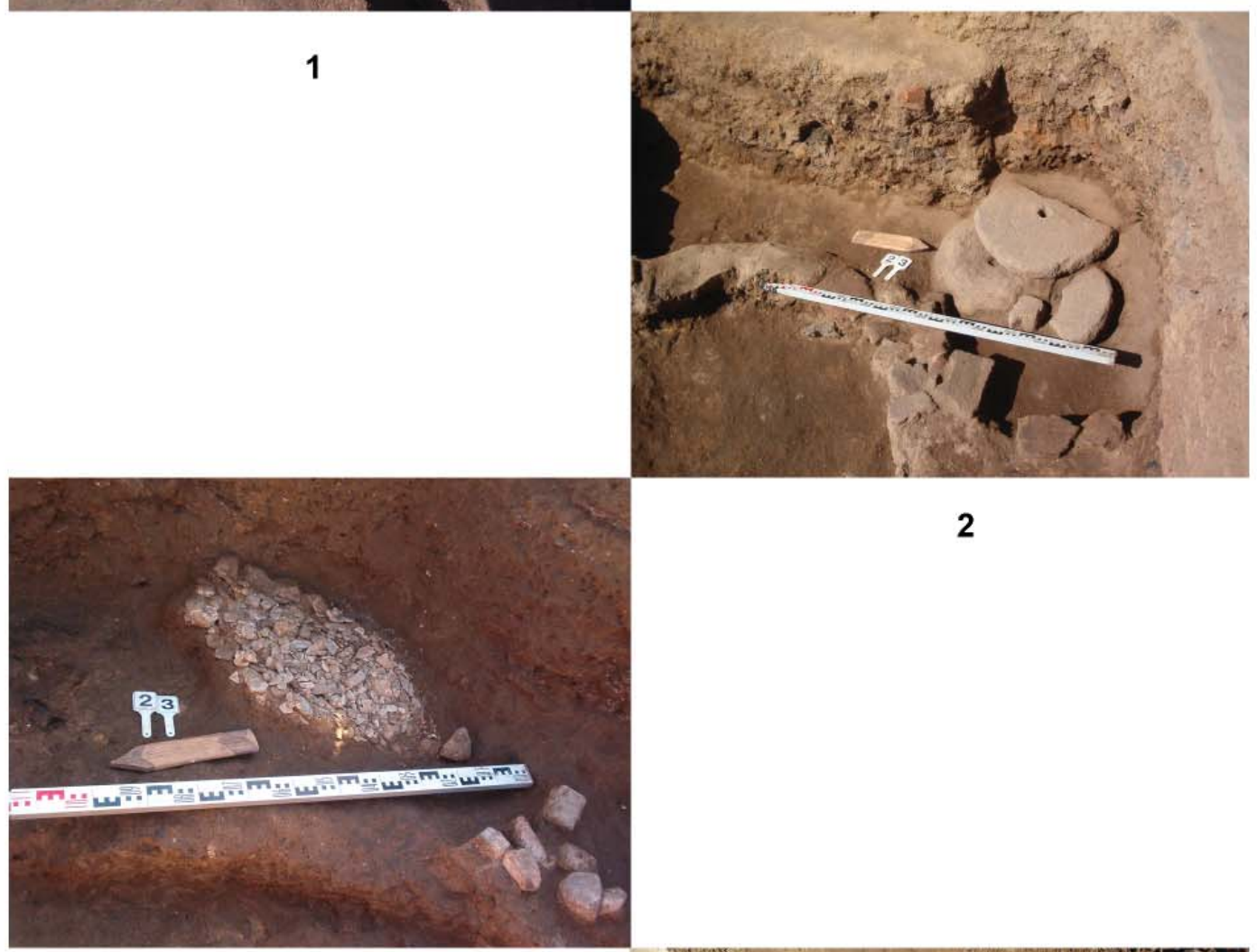

2

3

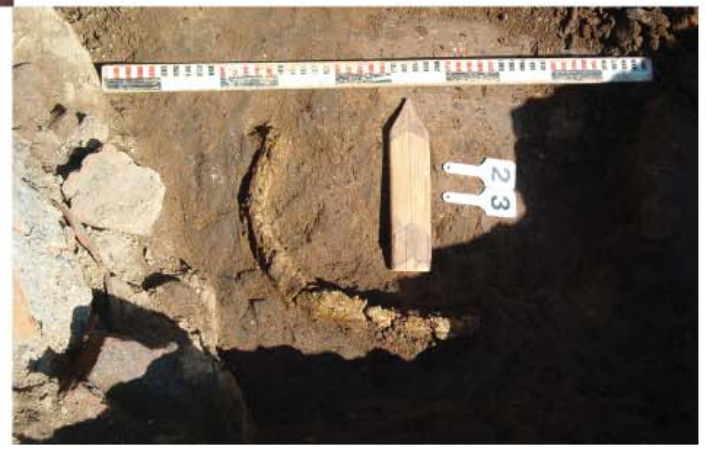

4

Рис. 3. Сооружение 23: 1 - развал хумчи в северо-восточном углу; 2 - жернова в северо-западном углу; 3 - скопление свинцовых слитков на южной суфе; 4 - железный предмет (серп?)

Fig. 3. Building 23: 1 - collapsed khumchi in the north-eastern corner; 2-millstones in the north-western corner; 3 - accumulation of lead ingots on the southern sufa; 4 - iron item (sickle?)

Яма землянки имела слоистое заполнение. В верхней части находились мощные (до 1 м) наслоения золы. Под ними был найден и расчищен слой тлена от камыша или тростника, который понижался к центру. Этот тлен, скорее всего, является остатком камышового перекрытия землянки, которое рухнуло уже после того, как она пришла в запустение. Под тленом залегал собственно слой заполнения землянки в виде зеленовато-серого комковатого суглинка с золой, углями, костями и керамикой. Выше тлена находился слой мусора, кото- 
рым засыпали землянку, чтобы снивелировать поверхность. В заполнении землянки на всех уровнях было большое количество костей, керамики, железных, медных и стеклянных предметов. Ту часть заполнения, которая находится ниже уровня рухнувшего перекрытия, можно считать закрытым комплексом.

Стены землянки были сложены из обломков обожженных кирпичей на глиняном раствоpe. Кирпичи квадратные, формат кирпичей разный. Размеры их сторон колеблются от 20 до $25 \mathrm{~cm}$, толщина - от 3,5 до 5 см. Некоторые кирпичи были крупноформатными со стороной 26-27,5 см и даже 31 см. Толщина их достигала 7 см. Стены постройки неровные, они сильно искривлены как в горизонтальном, так и в вертикальном направлениях в результате просадки культурного слоя.

Восточная стена землянки имела ширину 20-30 см и была сложена из обломков кирпичей в 2-3 ряда. Высота стены составляла 32 слоя кирпича (2 м от уровня пола) в южной части и 24 слоя (1,5 м) в северной части. Нижний слой кирпичей восточной стены начинался не с уровня пола, а уровня поверхности суфы, то есть на 4 слоя кирпичей (25-30 см) выше, чем прилегающая к ней южная стена. Кладка сделана на глиняном растворе, в перевязку. Кирпичи обкладки стены были явно использованы вторично, некоторые из них носили следы известковой обмазки. В 5,0 м от северо-восточного угла кирпичная обкладка стены становится сырцовой. Сырцы имели длину 24 см и толщину 6 см. Длина сырцового участка стены 1,0 м. Северный конец его выходит за пределы основного помещения землянки и образует стену коридора, ведущего в помещение с северной стороны. После разборки сырцового участка кладки в стене образовался проход шириной 1,0 м. Порог прохода был выложен обломками обожженных кирпичей на глиняном растворе. Кладка порога была сделана в 3 слоя. К какому строительному периоду относился данный проход, сказать сложно. Вероятно, к ранним периодам. Впоследствии этот проход был заложен и сделан другой в северной стене.

В 130 см от юго-восточного угла в кирпичной кладке восточной стены был сделан вертикальный разрыв. Он начинался с уровня на 70 см выше поверхности суфы и заканчивался на уровне 20 слоя кладки. Ширина его 10 см, высота 55 см. Он имел ровные границы, так что, очевидно, был сделан специально. С северной стороны разрыва в его нижней части находился прямоугольный участок размерами $23 \times 25$ см, лишенный кладки. В 120 см к северу от первого разрыва кладки находился еще один. Он начинался с уровня суфы, имел высоту 110 см и ширину 10 см. С северной стороны от этой вертикальной борозды на высоте 40 см от уровня суфы также был небольшой $(25 \times 22$ см) участок, лишенный кладки. Скорее всего, в эти разрывы кладки были вставлены деревянные брусья, которые придавали кладке большую прочность.

Южная стена имела высоту 16-17 слоев кирпичей от своего основания. Основание южной стены находилось на 4 слоя кирпичей ниже, чем основание восточной стены. В углу, образованном этими стенами, первые 4 слоя восточной стены и 8 слоев южной положены не в перевязку. Между ними имеется щель шириной 25 см в нижней части, которая постепенно сужается кверху. Выше кладка стен перевязана, для чего кирпичи в углу положены под углом $45^{\circ}$ к обеим стенам. В южной стене пятый, шестой, седьмой и восьмой слои кладки частично были сложены из сырцовых кирпичей большого формата. Длина их достигала 50 см, а толщина 78 см. В восточной части южной стены нижние 4-5 слоев кладки сильно просели. Этот прогиб был заполнен четырьмя слоями сырцовой кладки. Дальше к западу на кирпичной кладке лежат только два слоя сырца. Выше кладка была сделана из обломков кирпичей и имела такое же строение, как и восточная стена. В юго-западном углу землянки кладка южной стены сложена в перевязку с западной стеной только на уровне трех нижних слоев кладки. Выше кладка имеет неровный край, который не доходит до западной стены на 20-50 см. Это пространство было забутовано глиной. Таким образом, создается впечатление, что верхняя часть южной стены была положена на уже имевшуюся нижнюю часть, которая некоторое время существовала и успела просесть. Причем нижняя часть южной стены сложена в перевязку только с западной стеной, а верхняя часть перевязана с восточной стеной.

Разборка стены подтвердила это предположение. В верхней части стена была сложена из крупных и мелких обломков кирпичей в 2-3 ряда. Толщина ее достигала 50 см. Ниже слоя сырцов 4-5 слоев кладки сделаны из целых кирпичей размерами 23,5-24×23,5-24×4,5-5 см. Кладка в 1 ряд. Только в средней части стены, снаружи она немного доложена обломками.

Западная стена землянки шириной 25-35 см была сложена в 3 ряда из обломков 
кирпичей. В северной части она имела высоту 25 слоев кладки, а в южной части 13 слоев от основания. В 130 см от северо-западного угла верхняя часть кладки стены, начиная с седьмого слоя, выступает вовнутрь землянки на 20 см. Это стало возможно, так как в этой части не была соблюдена перевязка кирпичей, и образовался вертикальный шов. В нижней части (4 слоя) кладка идет вровень с остальной плоскостью стены. Более тщательное исследование этого участка стены позволило предположить, что здесь также имеется заложенный проход. Проход был заложен обломками обожженных кирпичей. Ширина его 60 см. Порог был образован четырьмя нижними слоями кладки. Этот проход мог относиться к первым четырем строительным периодам (рис. 4, 6: 2), так как впоследствии к западной стене была пристроена суфа.

Северный конец западной стены сложен в перевязку с северной стеной.

Северная стена имела в высоту 19-21 слой кирпича от основания (150-160 см). Ширина ее около 70 см. В северной стене имелся скользящий вдоль восточной стены проход шириной 80 см. Три нижних слоя кладки северной стены идут вплоть до восточной стены, где перевязываются с ней. Они сложены из сырцовых и обожженных кирпичей. Восточный конец этой кладки повышается примерно на 10-15 см, так как восточная стена стоит на земляной ступени. Выше все слои кладки, сложенные из обожженных кирпичей, образуют ровный торец, который является западной стенкой прохода. Сырцовый порог прохода был обложен досками. В углу, образованном нижними слоями кладки восточной и северной стен, в сырцовом заплыве было найдено отверстие для столбика диаметром $10 \mathrm{~cm} \mathrm{и}$ глубиной 10 см. Возможно, оно служило для крепления двери.

Проход в землянку был завален битым кирпичом. После разборки завала был расчищен коридор, ведущий в основное помещение землянки с северной стороны. Его длина 4,0 м, ширина 1,2-1,4 м. Восточная стена прохода являлась продолжением восточной стены землянки. Она была сложена из обломков обожженных кирпичей на глиняном растворе. Ширина еe 30-40 см. Южный конец стены длиной 40-45 см был сложен из сырцов. Облицовка стены кирпичами, повернутыми торцом к западу, сохранилась только в нижней части стены на высоту 3-5 слоев. Дальше прослеживалась толща стены из рваного кирпича. В 65 см от входа в основное помещение землянки в стене прослеживался вертикальный проем шириной 12-15 см и глубиной 12 см. Возможно, в нем был закреплен брус, поддерживавший крышу коридора.

Западная стенка коридора не сохранилась. Вероятно, из ее кирпичей состоял завал в проходе. Тем не менее на то, что коридор имел ширину 140 см, указывает строение северной стены землянки. Участок кладки стены, примыкающей к проходу в землянку, имеет ровный фасад не только с южной стороны, но и с северной. Длина его 60-70 см. Остальная кладка стены имеет рваный северный край, так как он примыкал к котловану землянки и не был виден. Таким образом, в землянку вел коридор шириной 140 см, который сужался на входе в землянку до $80 \mathrm{~cm}$. Пол его был земляным, он имел небольшой уклон к югу. Этот проход и коридор, ведущий в него, скорее всего, относятся к последнему периоду (рис. 5: 3).

Пол землянки был земляным. Он представлял собой темно-серый плотный суглинок, утоптанный до твердости асфальта. При прокопке пола в центре его была найдена яма для столба, который поддерживал крышу землянки, что позволяет предположить, что она была шатровой. Яма неправильно округлая в плане размерами $30 \times 30$ см, глубиной 40 см с плоским дном.

Вдоль всех четырех стен была сделана невысокая (15-25 см высотой) суфа. После выборки суфы в ее массиве появились остатки многочисленных стенок, которые можно отнести к семи строительным периодам.

I строительный период (рис. 4: 1).

В I строительном периоде была сделана Г-образная суфа вдоль южной и восточной стен. Южная суфа имела ширину 80 см в западной части и $50 \mathrm{~cm}$ в восточной. Подпорная стенка была сложена из обломков обожженных кирпичей на глиняном растворе и была 10-15 см шириной. Высота ее - 2-3 слоя. Восточная суфа имела ширину 55-60 см. В 2,3 м от южной стены землянки стена поворачивала на восток под тупым углом. Ширина ее подпорной стенки 10-15 см, высота - 2-3 слоя. Кирпичи укрепляли стенку суфы только в верхней части, нижняя была земляной.

II строительный период (рис. 4: 2).

Bo II строительном периоде стенка суфы была укреплена. С внешней стороны к стенке I периода была пристроена стенка из обломков кирпичей. В западной части она примыкала вплотную к южной стенке, I периода, а в восточной части отстояла от нее на 25-30 см. 


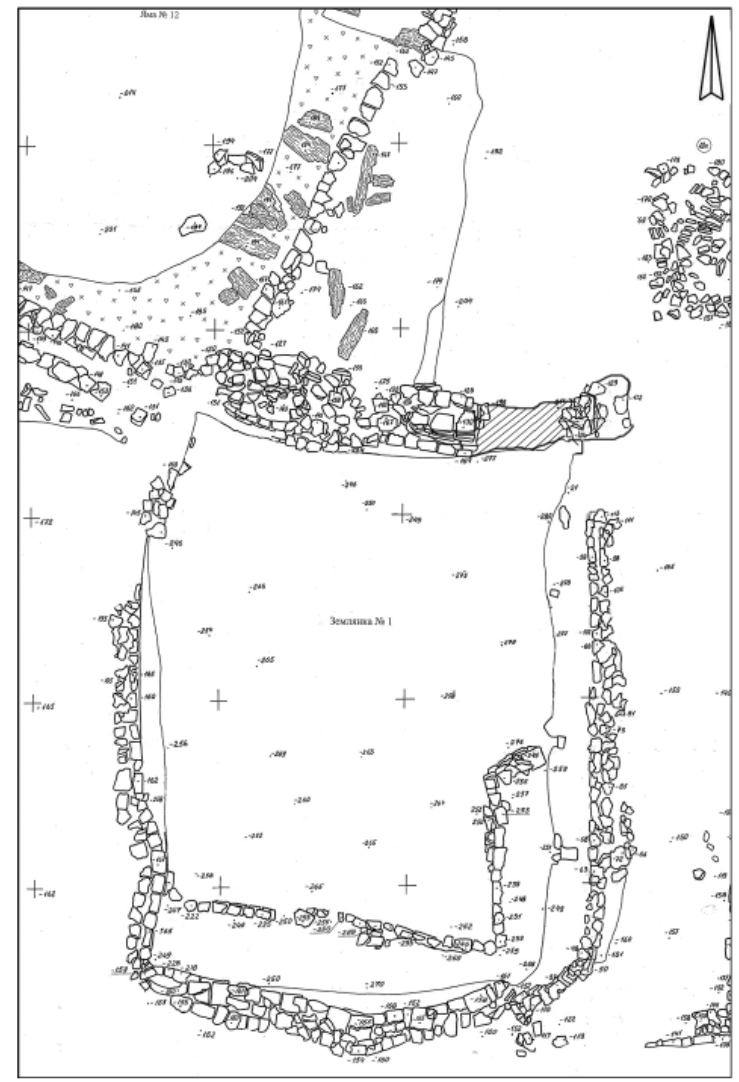

1

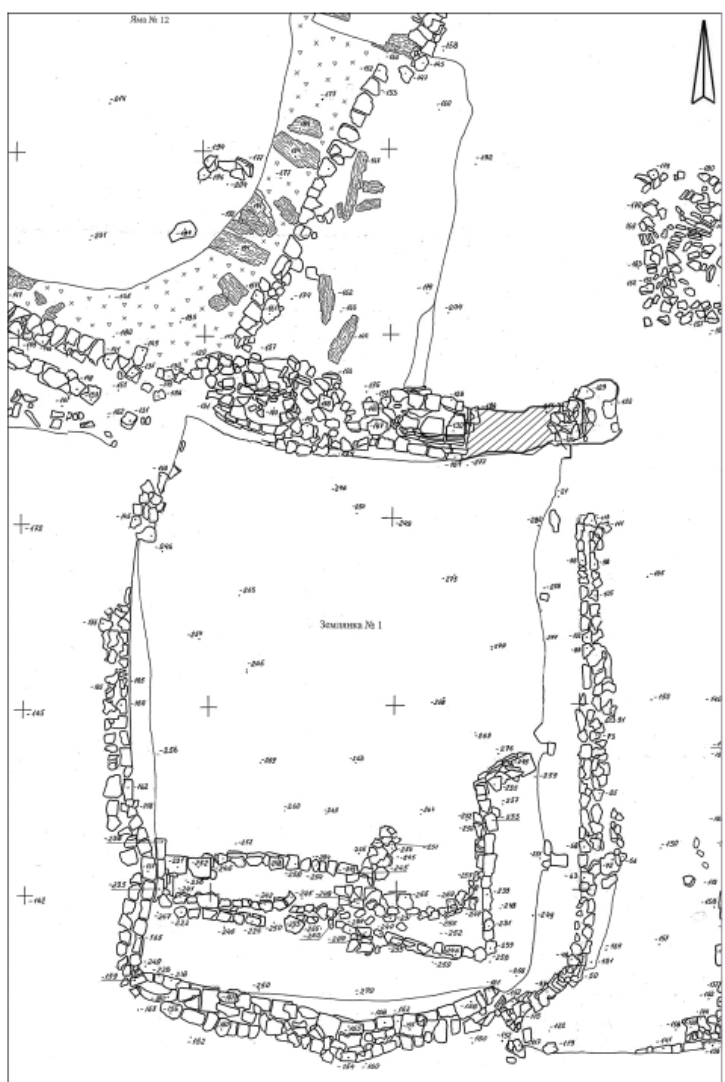

3

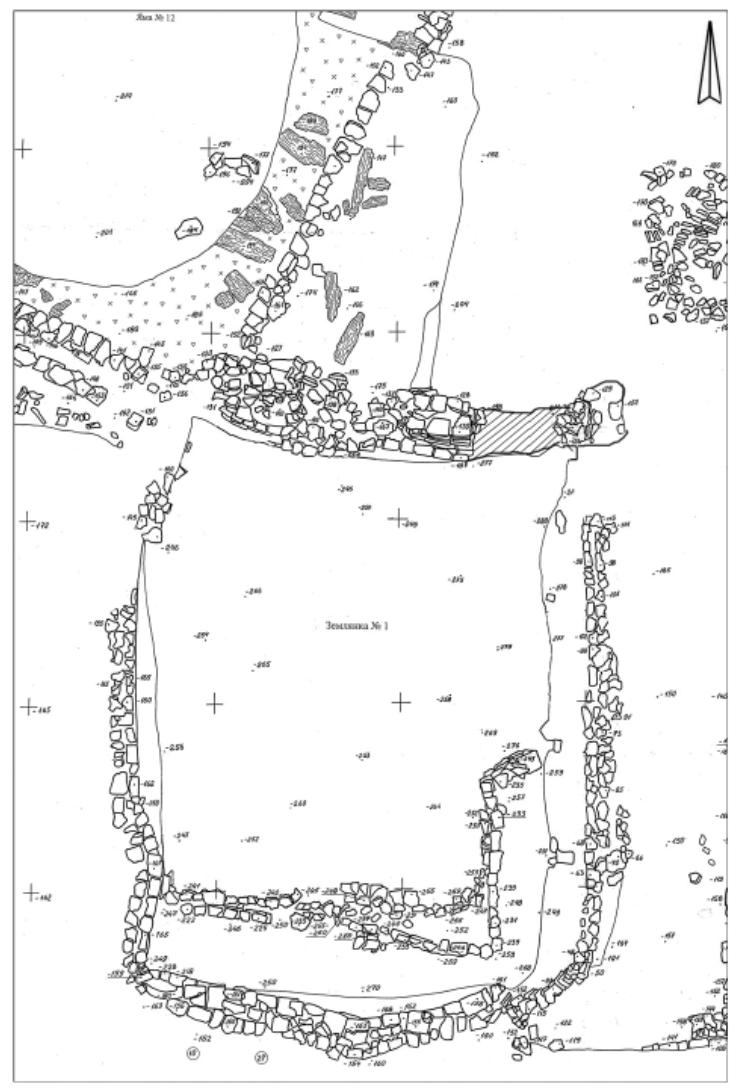

2

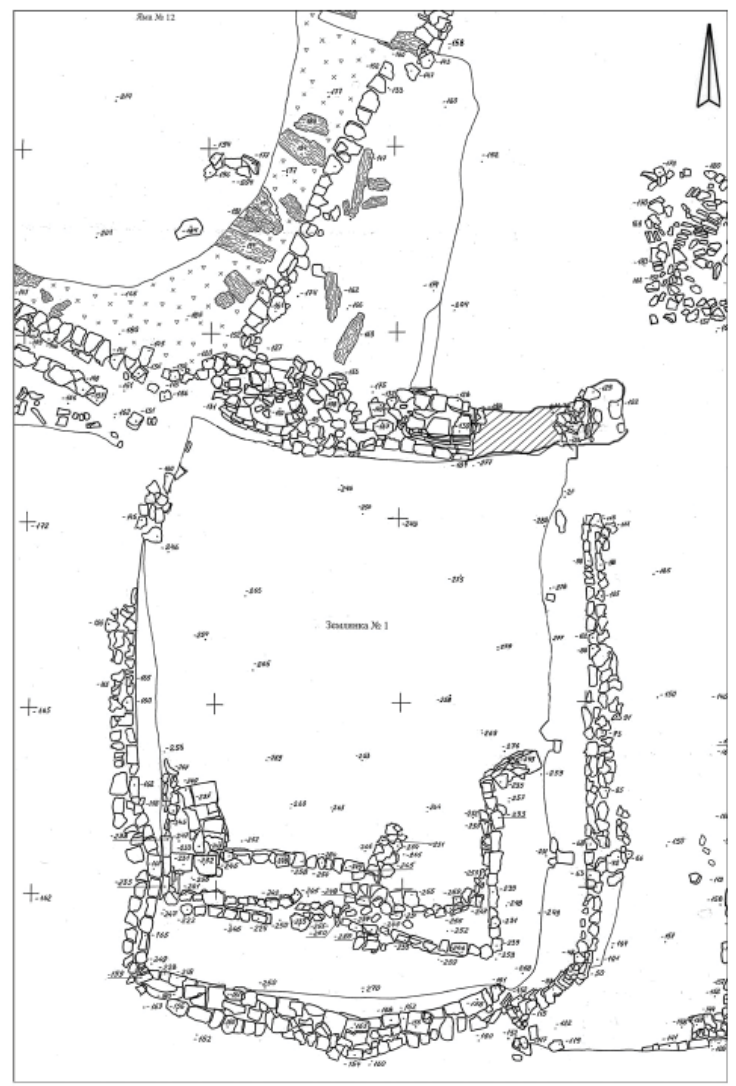

4

Рис. 4. Землянка № 1 планы перестроек: 1 - I период; 2 - II период; 3 - III период; 4 - IV период

Fig. 4. Dugout No. 1 reconstruction plans: 1 - period I; 2 - period II; 3 - period III; 4 - period IV 
Восточная стенка была пристроена вплотную к стенке I периода. Обе стенки сложены из мелких обломков кирпичей в 1-2 слоя. Ширина их 10-15 см. Ширина северной суфы во II строительном периоде - 100-110 см, восточной суфы -70 см. В средней части северной суфы видны следы ремонта: к ней снаружи был пристроен участок стены длиной 85 см и шириной 20 см из крупных обломков кирпичей, повернутых торцом наружу.

III строительный период (рис. 4: 3).

В III строительном периоде суфа была Г-образная, пристроенная к южной и восточной стенам. Ширина южной суфы $150 \mathrm{~cm}$, восточной - 150-180 см. Подпорная стенка южной суфы сложена из обломков кирпичей, обращенных торцом к северу. Ширина стены 15-20 см. Высота подпорной стенки - 3 слоя. Западный конец стенки сложен из целых кирпичей (2 кирпича), положенных в 2-4 слоя. Размеры кирпичей $-24 \times 24 \times 5$ см. Восточная стенка имела высоту 1-3 слоя. Угол между стенками находился на расстоянии 2,2 м от западной стены землянки. Угол тупой. Северный конец восточной стены суфы был разрушен стенкой южной суфы V периода.

IV строительный период (рис. 4: 4).

B IV строительном периоде была пристроена небольшая суфа вдоль западной стены, и вся суфа стала П-образной. Участок новой суфы имел размеры $80 \times 60 \times 70$ см. Стенка его сложена из целых кирпичей и половинок в 2 ряда. Ширина стенки 40 см, высота - 3-4 слоя.

V строительный период (рис. 5: 1).

В V периоде суфа примыкала к западной и южной стенам, а также южной части восточной стены. Подпорная стенка западной суфы находилась на расстоянии 1,0 м от стены землянки. Она сложена из мелких и крупных обломков кирпичей, обращенных торцом к востоку. Ширина ее 20-30 см, высота - 3-4 слоя. Стенка южной суфы находилась на расстоянии 180 см от стены. Она сложена из обломков кирпичей, ширина ее 10-20 см, высота 3-4 слоя. В 3,1 м от западной стены землянки стенка южной суфы поворачивает к югу, продолжается на 50 см и снова поворачивает к востоку, соединяясь со стенкой суфы I и II периодов.

VI строительный период (рис. 5: 2).

В VI строительном периоде суфа была П-образной вдоль западной, южной и восточной стен. Ширина южной суфы 2,3-2,5 м. Стенка ее сложена из обломков кирпичей, обращенных торцами к северу. Ширина стенки 15-20 см, высота - 5-7 слоев кладки. В южной суфе был сделан очаг. В юго-западном углу, образованным стенками суфы V периода, кладка третьего снизу слоя стенки южной суфы поворачивает к северу, образуя стенку полукруглой формы. Диаметр полукруга 50 см. Вероятно, эта стенка образовывала обкладку тандыра или круглой печи. Высота обкладки - 5 слоев.

Западная суфа осталось той же, только была слегка надстроена. Ее ширина 1 м, высота стенки 5-6 слоев кладки, ширина стенки 15-20 см. Кирпичи обращены торцами к востоку. Восточная суфа имела ширину $90 \mathrm{~cm}$ и длину 4,0 м от южной стены землянки. Ее подпорная стенка имела такое же строение, но высота ее составляла 3-4 слоя. В восточной суфе была сделана тошна. В 2,8 м от ЮВ угла землянки, вплотную к восточной стене был вкопан горлом вниз сосуд (хумча) с отбитым дном. Впоследствии сосуд был раздавлен, поэтому размеры его можно определить лишь приблизительно: диаметр горла 26 см, диаметр сосуда примерно 60 см, высота 50 см. При разборке этой тошны было обнаружено, что хумча вставлена в другой, разбитый сосуд аналогичной формы, то есть налицо следы ремонта.

VII строительный период (рис. 5: 3).

В VII строительном периоде суфа была сделана вдоль всех четырех стен. Южная и западная суфы остались прежними. Стенка восточной суфы была продолжена еще на $50 \mathrm{~cm}$ до соединения с подпорной стенкой северной суфы. Северная суфа шла вдоль всей северной стены. Проход в землянку вел прямо на суфу, а уже потом на пол. Суфа имела ширину $110-120$ см и высоту $2-5$ слоев кирпичей. В том месте, где суфа примыкала к проходу, уровень ее был несколько ниже, вероятно, оттого, что в здесь постоянно ходили. В восточной части северной суфы находился двухканальный кан длиной 150 см. Каналы его заканчивались у западной стены землянки. Стенки кана были сложены из крупных обломков кирпичей. Их ширина 15-20 см, высота - 4 слоя кладки. Ширина каналов 10-20 см. У западной стенки кана каналы соединялись. Каналы кана были перекрыты целыми кирпичами.

Кан отапливался тандыром, расположенным в центральной части суфы у ее южной стенки. Тандыр слегка расширялся книзу. Его верхний диаметр $32 \mathrm{~cm}$, нижний $-38 \mathrm{~cm}$. Высота тандыра 40 см. Устьем он открывался на юг. Ширина устья 20 см.

Возле входа, к западу от него, в суфе была устроена тошна, полукруглая в плане. Ее 


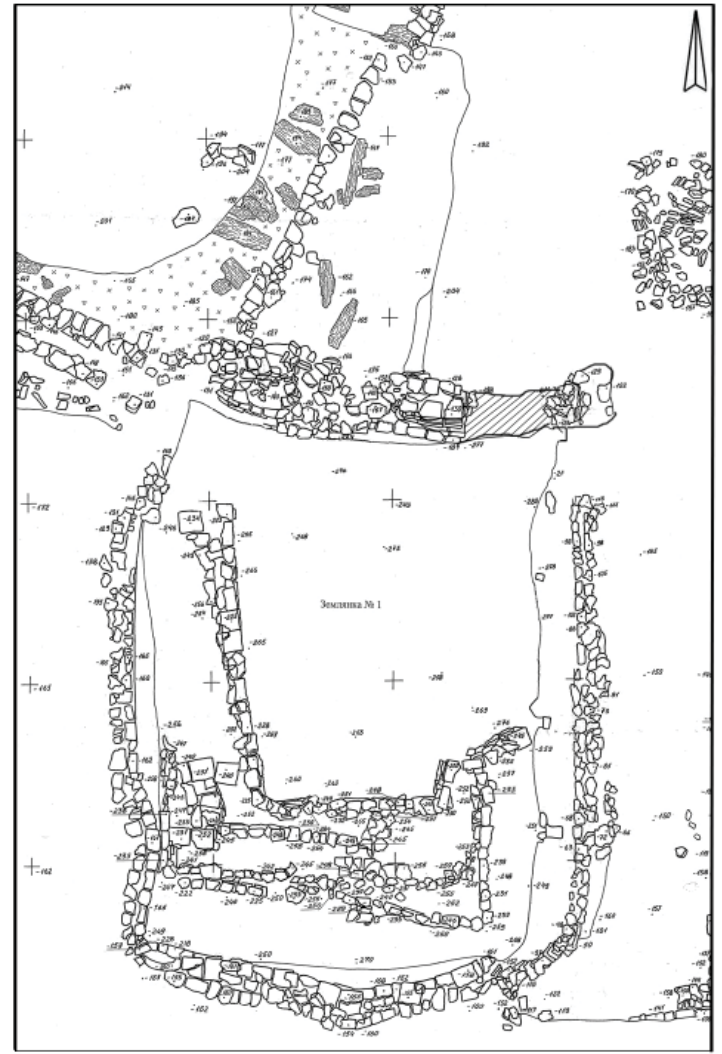

1

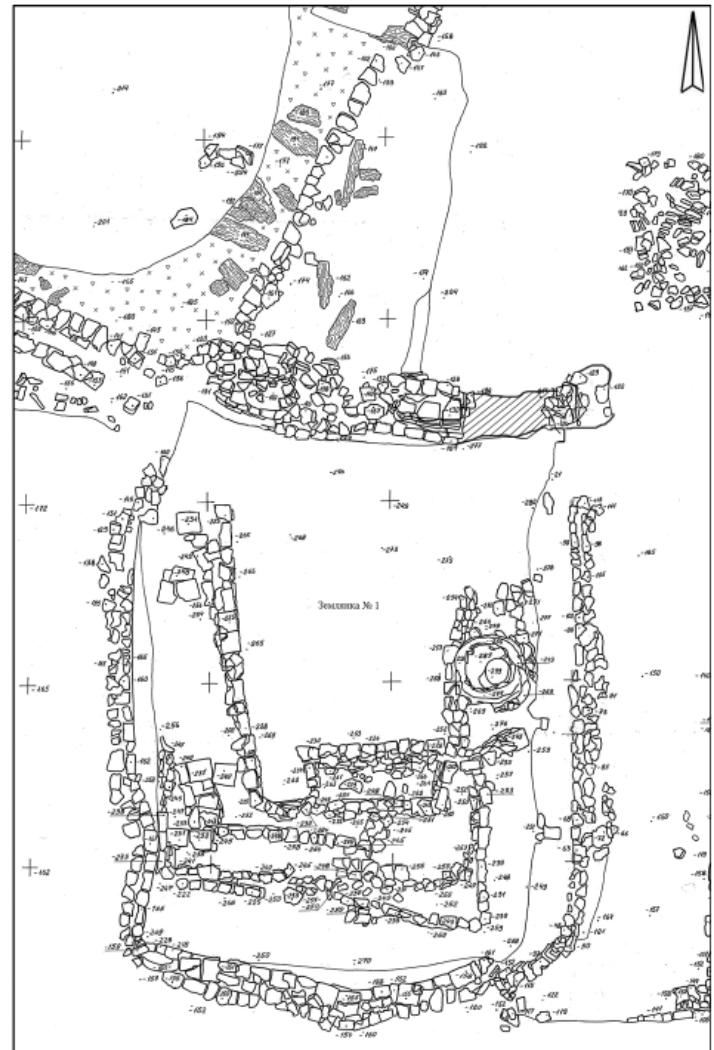

2

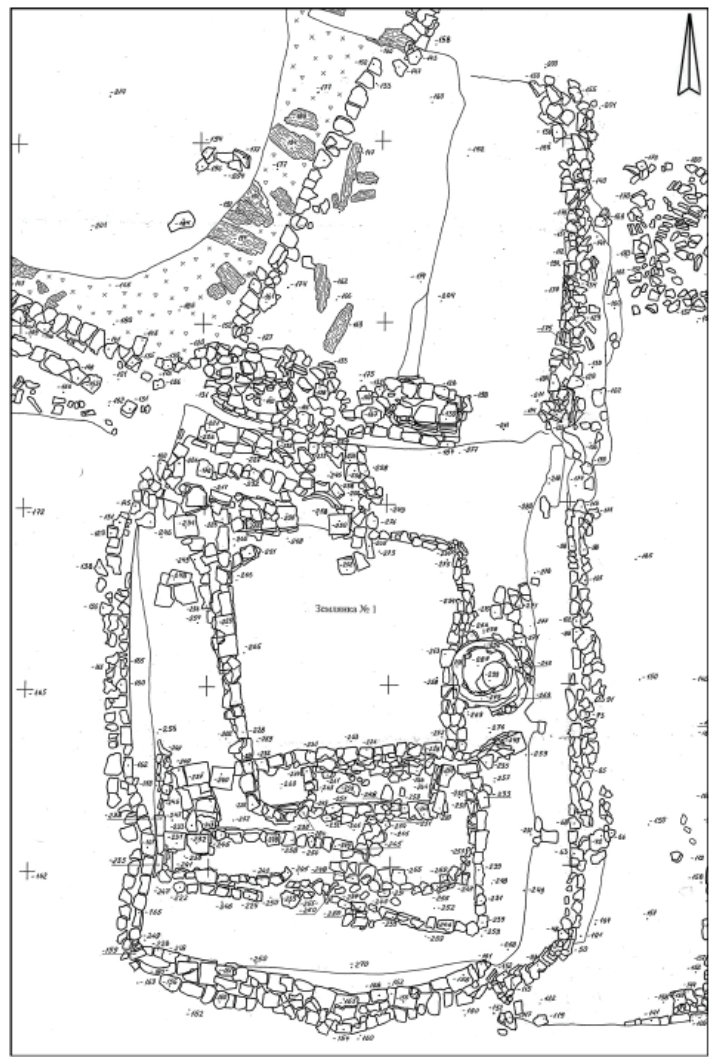

3

Рис. 5. Землянка № 1 планы перестроек: 1 - V период; 2 - VI период; 3 - VII период

Fig. 5. Dugout No. 1 reconstruction plans: 1 - period V; 2 - period VI; 3 - period VII 
диаметр 54 см. Колодец тошны был сложен из рваных обломков кирпичей. Кладка шла вглубь на 5 слоев.

В VII периоде печь в юго-западном углу суфы перестала функционировать. Ее устье было заложено кирпичами, которые продолжали линию стены южной суфы. Заклад начинался с четвертого снизу слоя кладки стены и был положен на заполнение печи. Поэтому в устье печи стенка сильно просела вниз. Также была засыпана и перекрыта поверхностью суфы тошна в восточной суфе.

Перестроек интерьера в землянке, скорее всего, было больше, так как некоторые обрывки стенок не укладываются в предложенную схему. Кроме того, при разборке конструкций землянки в полу были найдены остатки еще трех тандыров. Все это свидетельствует о длительности существования землянки.

В заполнении землянки было найдено большое количество фрагментов керамики, кости животных, а также множество предметов и их фрагментов из кости, стекла, камня, железа, меди, свинца. Как уже отмечалось, комплекс предметов, находящихся ниже уровня тлена от рухнувшей камышовой крышей, можно отнести ко времени существования землянки 1. Комплекс находок достаточно богатый и выразительный. В землянке было много фрагментов поливной ширванской керамики с росписью «сграффито» белого, зеленого, желтого и коричневого цветов, кашинная керамика с бирюзовой и синей поливой, а также росписью люстром, кашинные подвески, бусины, пуговицы. Довольно разнообразно представлены каменные изделия. Кроме стандартных оселков и пряслица это бирюзовая вставка, бусины из опала и горного хрусталя, кусочки гагата и янтаря. Наряду со стеклянными браслетами были найдены обломки тонкостенных стеклянных сосудов - флаконов, кувшинчиков, аламбиков. Здесь же находились фрагменты сфероконусов. Одновременная находка сфероконусов и аламбиков позволяет предположить, что в землянке могло быть какое-то химическое производство. О том, что постройка могла быть не только жилой, но и производственной, свидетельствует также большое количество так называемых костяных «коньков», которые применялись в выделке шкур и тканей (Семенов, 1959).

Землянку № 1 по керамике и стратиграфии можно датировать концом XII-XIII вв. Возможно, она доживает до начала XIV в.

Таким образом, сооружения 39 и 23 являются типичными полуземлянками. Обе они нежилые. В нижней части (ниже уровня дневного горизонта) стены их были земляными, так как никаких следов облицовки стен найдено не было. Верхняя часть стен сооружения 39 была турлучной. Стены сооружения 23 также были каркасными, но пространство между столбами каркаса было заполнено сырцами и, вероятно, обломками обожженных кирпичей. O перекрытиях никаких данных не имеется. Можно только предполагать, что они были плоскими или односкатными, крытыми камышом.

Близкие по форме и планировке полуземлянки были распространены на территории Хазарского каганата, например, в Саркеле (рис. 7), как в хазарское время, так и позже, когда на развалинах крепости стало проживать славянское население (Белецкий, 1959, с. 45-56; Плетнева, 1996, с. 40-48, 59-69; 2006, с. 17-18, 40-47, 51-55). Правда, у многих из них имеется ряд отличий от самосдельских. В некоторых жилищах жердевые ямки от каркаса стен находились не снаружи, вокруг котлована, а были выкопаны в его дне, то есть заглубленная часть стен имела облицовку. В отдельных постройках имелся один или два столба, поддерживающих крышу. И, наконец, в большинстве полуземлянок были расчищены очаги. Подобные сооружения исследованы и на других поселениях на Дону: Маяцком, Карнауховском и пр. (Ляпушкин, 1958, с. 285-305; Винников, Плетнева, 1998, с. 46-70).

В Волжской Болгарии полуземлянки также являлись распространенным типом жилища. Стенки их обшивались деревом, а в верхней части представляли собой срубы. Крыша была двускатной или шатровой, поддерживаемой центральным столбом. Отапливались помещения печами, которые топились по-черному. Такие полуземлянки известны на Тигашевском, Криушском II городище, Биляре, Джукетау, Болгаре (Хузин, 2006, с. 205-210; Полубояринова, 2016, с. 13-48). Некоторые постройки заглублены в землю на 2 м, т. е. являются землянками (Хузин, 2006, с. 210). В Болгаре полуземлянки прослеживаются вплоть до золотоордынского периода.

Совершенно уникальным сооружением является землянка № 1 на I раскопе Самосдельского городища. Это очень крупное сооружение площадью 26,3 м. Дно котлована заглублено более чем на 2 м. Все стены имеют кирпичную обкладку из крупных обломков обожженных кирпичей. Крыша постройки, возможно, была шатровой, покрытой камышом. Землянка существовала очень долго, 


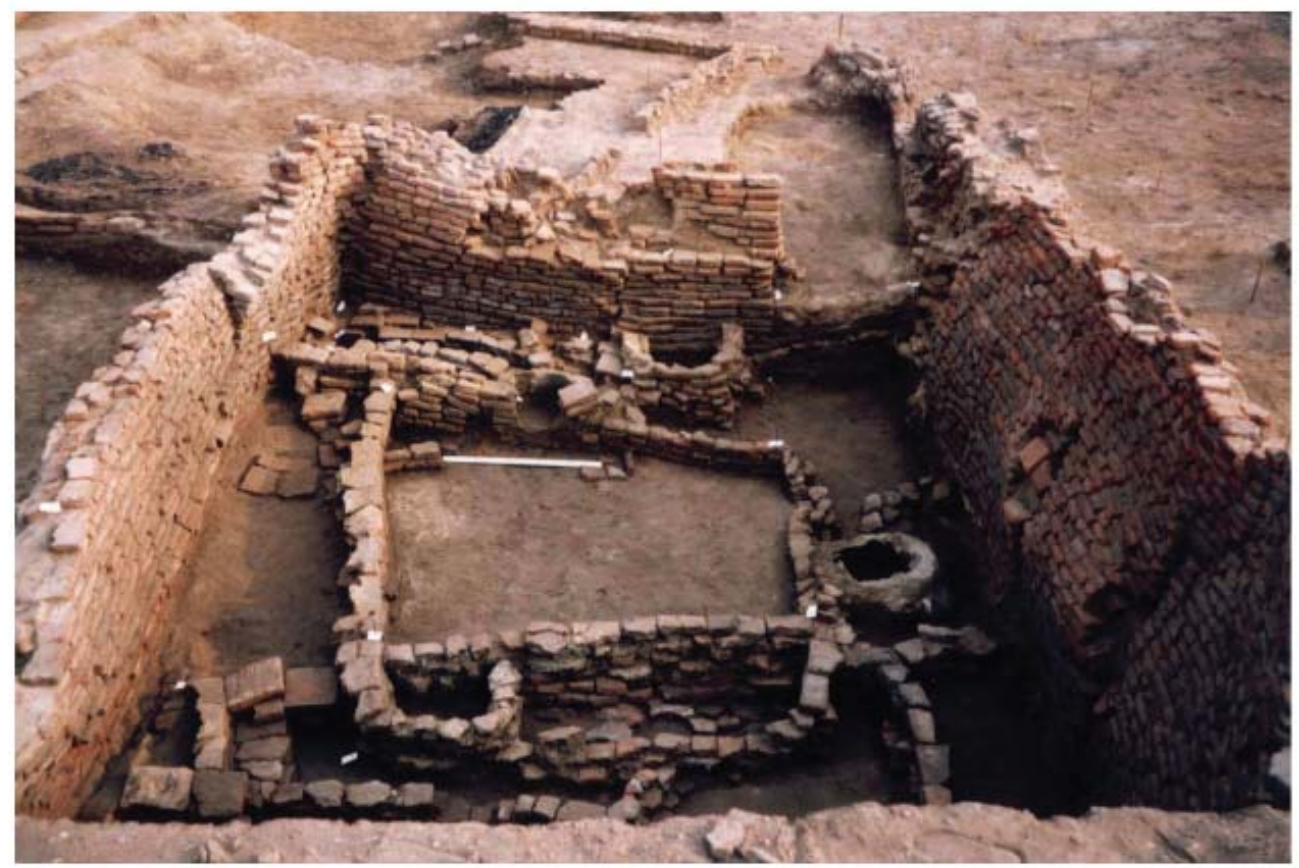

1

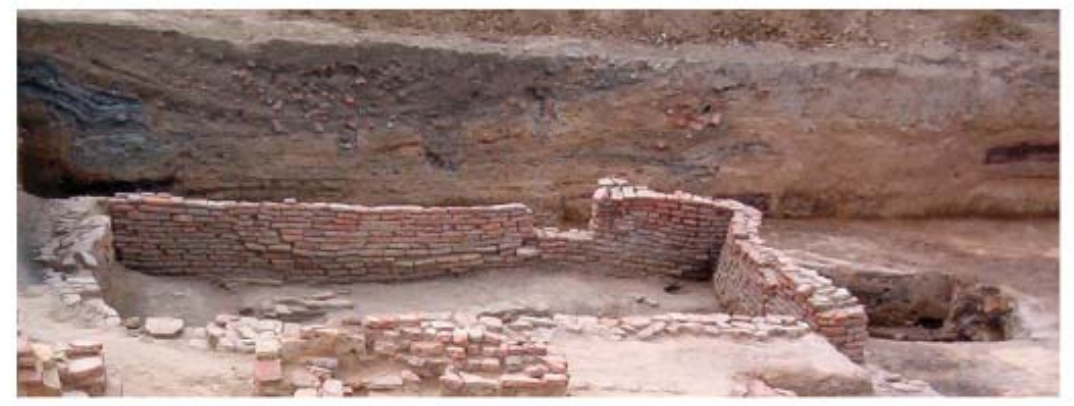

2

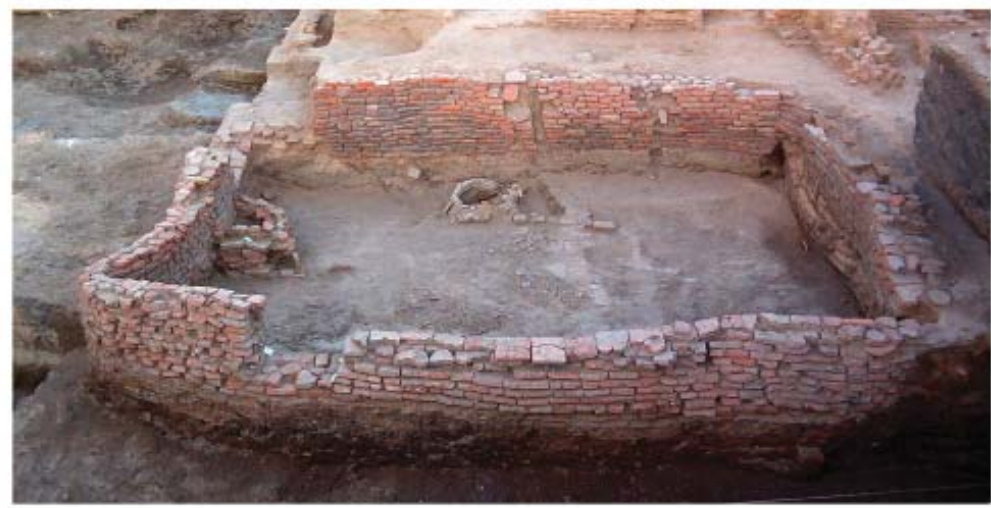

3

Рис. 6. Землянка № 1: 1 - общий вид с юга; 2 - проход в западной стене; 3 - вид с сапада после разборки внутренних конструкций.

Fig. 6. Dugout No. 1:1 - general view from the south; 2 - passage in the western wall; 3 - view from the west after the dismantling of internal structures.

так как в ее интерьере четко выделяются семь строительных периодов, хотя, скорее всего, перестроек было больше.

Подобные землянки или полуземлянки в Хазарском каганате и Волжской Болгарии неизвестны. Ее можно сравнить с более поздними землянками золотоордынских городов, где тоже известны достаточно большие постройки площадью 11-32 кв. м. Такие землянки не имели отопительной системы (как и землянка № 1 в первые периоды) и были предназначены для рабов и другого зависимого населения. Землянки меньших размеров с суфами и канами могли служить жилищами индивидуальным 


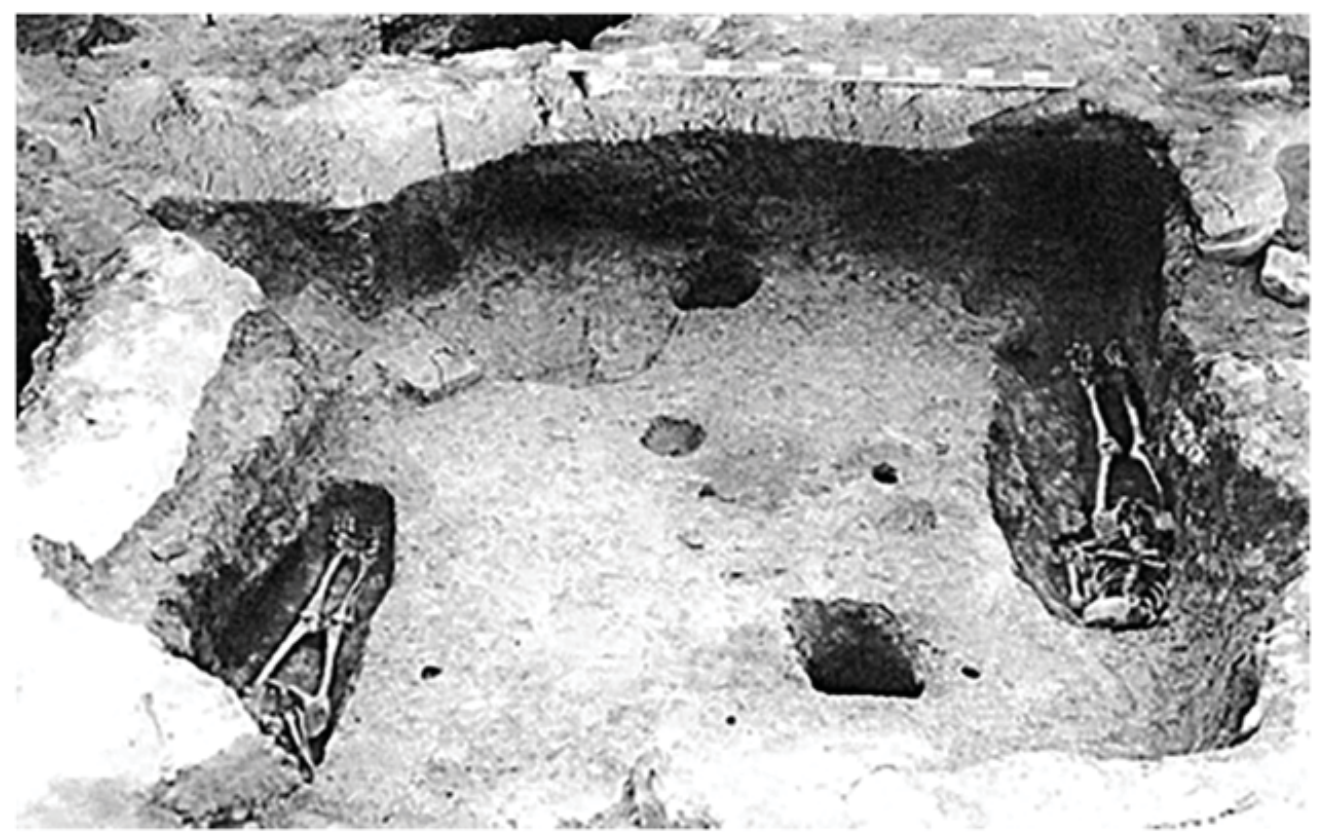

Рис. 7. Полуземлянка в Саркеле (по. М.И. Артамонов, 2002)

Fig. 7. Semi-dugout in Sarkel (after M.I. Artamonov, 2002)

семьям беднейшего населения городов (Федоров-Давыдов, 1994, с. 45-46). Но оформление интерьера самосдельской землянки и состав находок, происходящих из нее, свидетельствуют о том, что обитатели ее были довольно зажиточными людьми. По степени комфортности ее можно сравнить с двухкамерной землян- кой, раскопанной на XI раскопе Селитренного городища. Селитренская постройка состояла из двух помещений, соединенных коридором. Стены обеих комнат были обложены сырцовыми кирпичами. Одна камера не имела отопления, в другой находились суфа и кан (ФедоровДавыдов, 1994, с. 47).

\section{ЛИТЕРАТУРА}

Артамонов М.И. История хазар. СПб.: Из-во фил. Фак. СПГУ, 2002. 560 с.

Белецкий В.Д. Жилища Саркела - Белой Вежи. / МИА. № 62 / Отв. ред. М.И. Артамонов. М.-Л.: АН CCCP, 1958. С. 40-135.

Болдырева Е.М., Васильев Д.В., Зиливинская Э. Д. Юртообразные жилища и постройки Х-ХІІ вв. на Самосдельском городище // НАВ. 2020. Т. 19. № 1. С. 211-229.

Васильев Д.В. Город и область Саксин в свете новых данных археологии // Поволжская археология. 2015. № 2 (12). С. 189-267.

Винников А.З., Плетнева С.А. На северных рубежах Хазарского каганата. Маяцкое поселение. Воронеж: Из-во Воронежского государственного университета, 1998. 216 с.

Зиливинская Э.Д., Васильев Д.В. 2008. О вероятной локализации города Итиля на Самосдельском городище в дельте Волги // Труды II (XVIII) Всероссийского археологического съезда в Суздале / Отв. ред. А.П. Деревянко, Н.А. Макаров. Т. ІІ. М.: ИА РАН, 2008. С. 224-226.

Ляпушкин И.И. Карнауховское поселение // МИА. № 62 / Отв. ред. М.И. Артамонов. М.-Л.: АН СССР, 1958. С. 315-323.

Плетнёва С.А. Саркел и шелковый путь. Воронеж: Воронежск ун-тет, 1996. 168 с.

Плетнева С.А. Древнерусский город в кочевой степи. Воронеж: Из-во Воронежского государственного университета, 2006. 390 с.

Полубояринова М.Д. Жилища Болгара // Город Болгар: Жилища и жилая застройка / Отв. ред. А.Г. Ситдиков. М.: Наука, 2016. С. 5-192.

Семенов С.A. О назначении «коньков» и костей с нарезками из Саркела - Белой Вежи // МИА. № 75. М.-Л.: АН СССР, 1959. С. 353-362.

Флеров В.С. Раннесредневековые юртообразные жилища Восточной Европы. М., 1996. 100 с.

Федоров-Давыдов Г. А. Золотоордынские города Поволжья. М.: Изд. МГУ, 1994. 232 с. 
Хузин Ф.Ш. Городская застройка: жилые дома, хозяйственные постройки и общественные здания // История татар с древнейших времен. (в семи томах). Том II. Волжская Булгария и Великая Степь / Отв. ред. Ф. Ш. Хузин. Казань: Изд-во «РухИЛт», 2006. С. 205-227.

\section{Информация об авторе:}

Зиливинская Эмма Давидовна, доктор исторических наук, ведущий научный сотрудник, Институт этнологии и антропологии им. Н.Н. Миклухо-Маклая РАН, (г. Москва, Россия); eziliv@mail.ru

\section{REFERENCES}

Artamonov, M. I. 2002. Istoriya Khazar (History of the Khazars). Saint Petersburg: Saint Petersburg State Pedagogical University. (in Russian).

Beletsky, V. D. 1958. In Artamonov, M. I. (ed.). Materialy i issledovaniia po arkheologii SSSR (Materials and Research in the USSR Archaeology) 62. Moscow; Leningrad: the USSR Academy of Sciences, 40-135 (in Russian).

Boldyreva, E. M., Vasiliev, D. V., Zilivinskaya, E. D. 2020. In Nizhnevolzhskii arkheologicheskii vestnik (Lower Volga Archaeological Bulletin) 19 (1). 211-229 (in Russian).

Vasiliev D. V. 2015 In Povolzhskaya arkheologiya (Volga River Region Archaeology) 12 (2), 189-267 (in Russian).

Vinnikov, A. Z., Pletneva, S. A. 1998. Na severnykh rubezhakh Hazarskogo kaganata. Mayatskoe poselenie (On the Northern Borders of Khazar Kaganate. Mayaki Settlement). Voronezh: Voronezh State University (in Russian).

Zilivinskaya E.D., Vasiliev D.V. 2008. In Derevianko, A. P., Makarov, N. A. (eds.). Trudy II (XVIII) Vserossiiskogo arkheologicheskogo sezda $v$ Suzdale (Proceedings of the $2^{\text {nd }}\left(18^{\text {th }}\right.$ ) All-Russia Archaeological Congress in Suzdal) II. Moscow: Institute of Archaeology of the Russian Academy of Sciences, 224-226. (in Russian).

Lyapushkin, I. I. 1958. In Artamonov, M. I. (ed.). Materialy i issledovaniia po arkheologii SSSR (Materials and Research in the USSR Archaeology) 62. Moscow; Leningrad: the USSR Academy of Sciences, 315-323 (in Russian).

Pletneva, S. A. 1996. Sarkel i shelkovyi put' (Sarkel and the Silk Road). Voronezh: Voronezh University Publ. (in Russian).

Pletneva, S. A. 2006. Drevnerusskii gorod v kochevoi stepi (Old Russian Town in Nomadic Steppe). Voronezh: Voronezh State University (in Russian).

Poluboiarinova, M. D . 2016. In Sitdikov, A. G. (ed.). Gorod Bolgar: zhilishcha i zhilaia zastroika (Town of Bolgar: Dwellings and Residential Buildings). Moscow: "Nauka" Publ., 5-192 (in Russian).

Semenov, S. A. 1959. In Materialy i issledovaniia po arkheologii SSSR (Materials and Research in the USSR Archaeology) 75. Moscow-Leningrad: Academy of Sciences of the USSR, 353-362 (in Russian).

Flerov, V. S. 1996. Rannesrednevekovye iurtoobraznye zhilishcha Vostochnoi Evropy (Early Medieval Yurt-Shaped Dwellings of Eastern Europe). Moscow (in Russian).

Fedorov-Davydov, G. A. 1994. Zolotoordynskie goroda Povolzh 'ia (Golden Horde Towns in the Volga Area). Moscow: Moscow State University (in Russian).

Khuzin, F. Sh. 2006. In Istoriya tatar s drevnejshih vremen (v semi tomah) (History of the Tatars since ancient times (in seven volumes). 2 Kazan: "RukhIL" Publ., 205-227. (in Russian).

\section{About the Author:}

Zilivinskaya Emma D. Doctor of Historical Sciences. Institute of Ethnology and Anthropology named after N.N. Miklouho-Maklay (IEA), Russian Academy of Sciences. Leninsky Ave., 32a, Moscow,119334, Russian Federation; eziliv@mail.ru 